\title{
PENGARUH PEMBERIAN MINYAK ZAITUN (OLIVE OIL) TERHADAP RUAM POPOK PADA BAYI DI RSUD BANGKINANG TAHUN 2016
}

\author{
Apriza \\ Dosen Prodi Sarjana Keperawatan FIK Universitas Pahlawan Tuanku Tambusai \\ suksespenting@gmail.com
}

\begin{abstract}
ABSTRAK
Berdasarkan data yang dikeluarkan oleh World Health Organization (WHO) pada tahun 2009 prevalensi iritasi kulit (ruam popok) pada bayi cukup tinggi, 25\% dari 6.840.507.000 bayi yang lahir di dunia. Penelitian ini bertujuan untuk menganalisis pengaruh pemberian minyak zaitun (olive oil) terhadap ruam popok pada bayi di RSUD Bangkinang. Minyak zaitun (olive oil) salah satu terapi topikal yang dapat digunakan untuk mengatasi ruam popok. Desain penelitianini menggunakan metode eksperimen semu (quasi exsperimen) dengan rancangan non-equivalent pretest-posttest. Metode non-equivalent pretest-posttest ini digunakan untuk melihat pengaruh pemberian minyak zaitun (olive oil) terhadap ruam popok pada bayi, dengan jumlah sampel sebanyak 15 bayi. Analisa yang digunakan adalah analisa univariat dan analisa bivariat. Hasil penelitian ini menunjukkan bahwa sebelum pemberian minyak zaitun (olive oil) ruam popok pada bayi paling banyak pada derajat sedang yaitu 10 responden (66.7\%) sedangkan sesudah pemberian minyak zaitun (olive oil) ruam popok pada bayi paling banyak pada derajat ringan yaitu 7 responden (46.6\%). Uji t-test dependent menunjukkan nilai $P$ value $=0,000(\leq 0,05)$. Sehingga dapat disimpulkan bahwa ada pengaruh pemberian minyak zaitun (olive oil) terhadap ruam popok pada bayi di RSUD Bangkinang tahun 2016. Penelitian ini dapat di aplikasikan dalam asuhan keperawatan pada bayi yang mengalami ruam popok.
\end{abstract}

Kata Kunci : Ruam Popok, Minyak Zaitun, Bayi

\section{PENDAHULUAN}

\section{LatarBelakang}

Seorang individu dalam rentang kehidupannya akan melalui berbagai macam fase atau periode seiring dengan perkembangan usia. Salah satu periode yang memegang peranan penting dalam perkembangan seorang individu adalah periode bayi. Periode ini merupakan salah satu periode terpenting dan kritis dalam kehidupan.
Hal ini dikarenakan pada periode ini, seorang bayi mulai belajar dan memahami berbagai macam hal dan pengalaman baru tentang dirinya untuk menyesuaikan diri dengan lingkungan agar tercapai kesehatan yang optimal. Salah satu perawatan yang penting dilakukan pada bayi adalah perawatan kulit (Perry \& Potter, 2005).

Kulit merupakan organ tubuh tengsi utama sebagai sawar antara organ 
internal dengan lingkungan sekitarnya. Selain itu, keadaan kulit juga merupakan "cermin" kesehatan tubuh seseorang. Para orangtua semakin menyadari bahwa menjaga kesehatan kulit anak sama pentingnya dengan menjaga kesehatan anak secara umum. Dan untuk menjaga kesehatan kulit, diperlukan perawatan sejak usia dini. Perawatan kulit juga mengekspresikan rasa cinta seorang ibu pada buah hatinya. Telah dibuktikan bahwa sentuhan ibu akan sangat berpengaruh pada perkembangan fisik dan mental seorang anak. (Ardhie, 2002).

Dalam perawatan kebersihan bayi dan balita, hingga saat ini memakaikan popok pada bayi dan balita merupakan cara yang paling praktis, efektif, dan hygienis untuk menampung urin (BAK) dan faces (BAB) agar tidak menyebar pada saat buang air kecil maupun buang air besar. Namun sesungguhnya, kulit bayi dan balita tidak siap untuk mengatasi keadaan yang dapat timbul akibat kontak lama dengan urine dan faces yang disebabkan oleh pemakaian popok. Walaupun berbagai usaha telah dilakukan untuk mendapatkan popok yang ideal, ruam popok masih merupakan salah satu masalah kulit yang terdapat pada bayi dan balita. Kurang dari $50 \%$ bayi dan balita yang menggunakan popok pernah menderita ruam popok. Pemakaian popok pada bayi/balita merupakan kebutuhan kehidupan sehari-hari yang menuntut kepraktisan dan efektifitas yang tinggi. Namun oleh karena cara penggunaan popok yang salah, dapat menimbulkan dampak yang merugikan, yaitu bisa menyebabkan ruam popok pada bayi atau balita, dengan mengetahui apa penyebab dan pencegahannya, diharapkan terjadinya ruam popok pada bayi atau balita akan berkurang (Sugito, 2002).

Popok dan bayi adalah dua hal yang tak bisa dilepaskan. Popok bisa membuat bayi tenang tapi bisa juga justru jadi sumber kerewelan bayi. Dan semua itu bergantung pada seberapa jeli orangtua mendeteksi kehadiran ruam popok. Diantara sejumlah gangguan kulit pada bayi, ruam popok adalah yang paling sering terjadi pada bayi baru lahir. Bila kulit di sekitar bokong bayi meradang, berwarna kemerahan. Itu tandanya bayi terkena ruam popok. Biasanya, ruam kulit ini membuat bayi merasa gatal. Disebut ruam popok (diaper rash) Karena gangguan kulit ini timbul di daerah yang tertutup popok, yaitu sekitar alat kelamin, bokong, serta pangkal paha bagian dalam ( Hidayat, 2011, dalam Ramba, 2014).

Ruam popok adalah kelainan kulit (ruam kulit) yang timbul akibat radang di daerah yang tertutup popok, yaitu di alat kelamin, sekitar dubur, bokong, lipat paha, dan perut bagian bawah. Penyakit ini sering terjadi pada bayi dan anak balita yang menggunakan popok, biasa nya pada usia kurang dari 3 tahun, paling banyak pada usia 9 sampai 12 bulan (Sugito, 2002).

Berdasarkan data yang dikeluarkan oleh World Health Organization (WHO) pada tahun 2009 prevalensi iritasi kulit (ruam popok) pada bayi cukup tinggi. $25 \%$ dari 6.840 .507 .000 bayi yang lahir di dunia kebanyakan menderita iritasi kulit (ruam popok) akibat penggunaan popok. Angka terbanyak ditemukan pada usia 6-12 bulan. Insiden ruam popok di Indonesia mencapai $7-35 \%$, yang menimpa bayi 
laki-laki dan perempuan berusia dibawah 3 tahun (Andi, 2012, dalam Ramba, 2014).

Infeksi kulit pada bayi dan anak di Indonesia masih sering dijumpai, baik infeksi bakteri, virus, maupun parasit dan jamur. Hal ini disebabkan karena kulit anak yang relatif lebih tipis dan ikatan antar sel yang masih longgar, serta sawar kulit terhadap infeksi lemah. Hal ini juga didukung oleh kelembaban yang tinggi di daerah tropis, higiene bayi dan anak yang masih bergantung pada orangtuanya, higiene lingkungan yang kurang baik, imunitas seluler yang belum sempurna. Infeksi kulit di negara yang sudah maju sudah jarang didapatkan, sebaliknya dinegara berkembang dan belum maju dapat dikatakan infeksi kulit masih sering dijumpai. Selain faktor predisposisi pada individu, antara lain sawar kulit, gizi, higiene perorangan, faktor lingkungan, faktor lingkungan (Higiene lingkungan, suhu, kelembaban, dan letak geografis), kepadatan penduduk yang tinggi, patogenitas kuman dan virulensi mikroorganisme berperan penting pada terjadinya penyakit infeksi. Indonesia termasuk negara berkembang, dari data yang diperoleh ternyata infeksi kulit sering dijumpai baik dikota kecil maupun dikota besar. Dipusat kesehatan masyarakat (PUSKESMAS) maupun dirumah sakit rujukan, ratarata infeksi kulit menduduki peringkat ke-2 setelah dermatitis (Budiardja, 2005).

Penyebab ruam popok bersifat multifaktor faktor fisis, kimiawi, enzimatik dan biologik (kuman dalam urine dan faces). Peningkatan kelembaban kulit mempermudah kerusakan kulit akibat gesekan kulit dengan popok, Pemakaian popok yang lama tidak segara mengganti popok setelah bayi atau anak BAK atau BAB (Lokanata, 2004). Kontak yang lama dan berulang dengan bahan iritan, terutama urine dan faces, bahan kimia pencuci popok seperti sabun, detergen, pemutih, pelembut pakaian, dan bahan kimia yang dipakai oleh pabrik pembuat popok disposable juga dapat menyebabkan ruam popok (Wong, 1993, dalam Nursalam, 2005).

Gejala ruam popok bervariasi dapat bersifat ringan sampai parah/berat Pada gejala awal kelainan derajat ringan kemerahan ringan dikulit daerah popok yang bersifat terbatas, disertai dengan lecet atau luka ringan pada kulit. Kelainan derajat sedang berupa kemerahan dengan atau tanpa bintilbintil yang tersususun di sekitarnya seperti satelit, disertai lecet-lecet yang meliputi permukaan luas, biasanya terasa nyeri dan tidak nyaman. Pada ruam popok yang parah ditemukan kemerahan yang hebat disertai dengan bintil-bintil bernanah yang meliputi daerah kulit yang luas.

Pengobatan dan pencegahan ruam popok dapat dilakukan dengan terapi farmakologi seperti pemberian salap seng oksida (zinc oxide) dan salap kortikosteroid (Lakonata, 2004). Sedangkan terapi non farmakologi, Salah satu dari bahan olahan alami yang dapat dipertimbangkan sebagi terapi topikal alternatif yang dapat digunakan untuk perawatan kulit pada bayi yang mengalami ruam popok yaitu: meggunakan minyak zaitun karena minyak zaitun akan menjaga kelembaban kulit. Minyak zaitun bersifat dingin dan lembab dan dipergunakan untuk meremajakan 
kulit. Minyak zaitun mengandung banyak senyawa aktif seperti fenol, tokoferol, sterol, pigmen, squalene dan vitamin E. Semua senyawa ini bermanfaat untuk kulit, memperbaiki sel-sel kulit yang rusak sebagai antioksidan penetral radikal bebas mengurangi bekas kemerahan pada kulit dan dapat melindungi kulit dari iritasi. Minyak zaitun dapat dijadikan body lotion untuk menjaga kelembaban kulit (Apriyanti, 2012).

Minyak zaitun memiliki zat yaitu linoleic acid yang mampu menjaga air menguap, sehingga zat ini amat baik untuk digunakan sebagai pelembab kulit. Menurut Leslie Baumann, M.D, penulis the skin type solution, mengkunsumsi buah dan minyak zaitun bisa memberikan kulit sehat, begitu juga dioleskan (Fathoni, 2010).

Berdasarkan data primer yang didapat oleh peneliti dengan teknik wawancara dengan orangtua bayi dan di observasi, diruang rawat inap anak RSUD Bangkinang, didapatkan 7 bayi yang dirawat, 2 dari bayi yang dirawat mengalami ruam popok sedang, 3 bayi mengalami ruam popok ringan dan 2 bayi lagi tidak mengalami ruam popok.

Dari hasil observasi di ruangan anak RSUD Bangkinang, peneliti menyimpulkan terdapat masalah kenapa terjadi ruam pada bayi, salah satunya bayi yang terkena penyakit diare dan kurangnya pengetahuan ibu tentang penyebab dari ruam popok, kecendrungan kesalahan dalam pemakaian popok yang salah dapat menggangu kesehatan kulit pada bayi. Pemakaian popok yang salah seperti: melebihi daya tampung popok, tidak segera mengganti popok bayi setelah bayi BAB, tidak membersihkan bokong bayi dan alat genitalia bayi setelah BAK/BAB atau sebelum memakaikan popok yang baru, pemakaian popok yang terlalu ketat, sehingga udara tidak masuk membuat kulit bayi menjadi lembab dan keadaan tersebut mempermudah tumbuhnya bakteri.

\section{Rumusanmasalah}

Adakah pengaruh pemberian minyak zaitun (olive oil )terhadap ruam popok pada bayi?

\section{Tujuan Penelitian}

Untuk mengetahui pengaruh pemberian minyak zaitun terhadap ruam popok pada bayi.

\section{METODE PENELITIAN}

\section{Desaian Penelitian}

Desain penelitian ini menggunakan metode eksperimen semu (Quasi experimen) dengan rancangan (one group pre-test - one group post test design).Intervensi yang digunakan dalam penelitian ini adalah pemberian minyak zaitun $2 \mathrm{x}$ sehari pada pagi dan sore hari selama 3 hari berturut-turut. Metode non-equivalent pretestposttest ini digunakan untuk melihat pengaruh pemberian minyak zaitun (olive oil) terhadap ruam popok pada bayi di RSUD Bangkinang tahun 2016.

\section{Tempat dan Waktu Penelitian}

Penelitian ini dilakukan di Ruang Rawat Inap Anak RSUD Bangkinang Kabupaten Kampar pada bulan Mei 2016.

\section{Populasi dan Sampel}

Populasi dalam penelitian ini adalah 31 bayi yang dirawat inap di RSUD Bangkinang tahun 2016. 
Sampel

\begin{tabular}{|c|c|c|}
\hline Variabel & $\mathbf{F}$ & $\%$ \\
\hline $\begin{array}{l}\text { Umur } \\
\text { - } 0-6 \text { bulan } \\
\text { - } 7-12 \text { bulan }\end{array}$ & $\begin{array}{c}11 \\
4\end{array}$ & $\begin{array}{l}73.3 \% \\
26.7 \%\end{array}$ \\
\hline Jumlah & 15 & $100 \%$ \\
\hline $\begin{array}{l}\text { Jeniskelamin } \\
\text { - Perempuan } \\
\text { - Laki-laki }\end{array}$ & $\begin{array}{l}6 \\
9 \\
\end{array}$ & $\begin{array}{l}40 \% \\
60 \% \\
\end{array}$ \\
\hline Jumlah & 15 & $100 \%$ \\
\hline $\begin{array}{l}\text { Sampelyang dig } \\
\text { yang mengalami } \\
\text { dirawat inap di } \mathrm{D} \\
\text { yang memenuhi } \\
\text { ekslusi yaitu } \\
\text { pengambilan san } \\
\text { accidental sampli }\end{array}$ & $\begin{array}{l}\text { SUL } \\
\text { teria } \\
5\end{array}$ & $\begin{array}{l}\text { lah bayi } \\
\mathrm{k} \text { yang } \\
\text { ngkinang } \\
\text { lusi dan } \\
\text { yi.Teknik } \\
\text { igunakan }\end{array}$ \\
\hline
\end{tabular}

\section{Alat Pengumpulan Data}

Alat pengumpulan data pada penelitian inimenggunakanlembar observasi, yang diisiolehpenelitiberdasarkanobservasila ngsungkebayidanmewawancaraiibu. Isi lembar observasi merupakan sejumlah klasifikasi derajat ruam popok berdasarkan tanda dan gejala ruam popok tertulis yang digunakan untuk memperoleh data dari responden.

\section{Analisa Data}

Analisa yang digunakan adalah analisa univariat dan analisa bivariat. Analisa bivariat digunakan untuk menganalisa perbedaan derajat ruam popok responden sebelum dan setelah pemberian minyak zaitun (olive oil) selama 3 hari berturut-turut dengan frekuensi pemberian 2 kali sehari pada pagi dan sore hari. Dalam analisis ini peneliti menggunakan uji statistik dengan uji T-test atau paired T-test yaitu uji dua mean dependent. Perbedaan derajat ruam popok responden sebelum dan setelah pemberian minyak zaitun (olive oil).

\section{HASIL PENELITIAN \\ Analilsa Univariat \\ Tabel 4.1 Distribusi Frekuensi \\ Karakteristik Responden di RSUD \\ Bangkinang $(n=15)$}

Berdasarkantabel $4.1 \quad$ dapat diketahuibahwa sebagian besar responden berada pada kategori umur 0 -

6bulanyaitusebanyak11 responden $(73.3$

$\%$ ),sebagianbesar

respondenberjeniskelaminlaki-

lakiyaitusebanyak9 responden $(60 \%)$.

Tabel 4.2 Distribusi Responden Berdasarkan Derajat Ruam Popok Sebelum Dan Sesudah Pemberian Minyak Zaitun (Olive Oil) Di RSUD Bangkinang

\begin{tabular}{lllll}
\hline $\begin{array}{l}\text { Deraj } \\
\text { at } \\
\text { ruam } \\
\text { popok }\end{array}$ & $\begin{array}{l}\text { Seb } \\
\text { elu }\end{array}$ & m & $\begin{array}{l}\text { Sesu } \\
\text { dah }\end{array}$ & $\%$ \\
\hline $\begin{array}{c}\text {-Tidak } \\
\text { adaru }\end{array}$ & 0 & $0 \%$ & 5 & 33.3 \\
am & & & & $\%$ \\
-Sanga & 0 & $0 \%$ & 3 & $20 \%$ \\
tringa & & & & 46.6 \\
n & 5 & 33.3 & 7 & $\%$ \\
-Ringa & 0 & $\%$ & 0 & \\
n & & $0 \%$ & & 0 \\
-Ringa & 10 & & 0 & 0 \\
n/ & 0 & 66.7 & 0 & 0 \\
$\begin{array}{l}\text { Sedan } \\
\text { g }\end{array}$ & 0 & $\%$ & 0 & \\
-Sedan & & & & \\
g & & 0 & & \\
-Sedan & & & & \\
g/ & & & & \\
\hline
\end{tabular}




\begin{tabular}{llll}
\hline $\begin{array}{c}\text { Berat } \\
\text {-Berat }\end{array}$ & & & \\
& 15 & $100 \%$ & 15 \\
\hline
\end{tabular}

Tabel 4.2 menunjukkan bahwa sebelum pemberian minyak zaitun (olive oil) ruam popok pada bayi paling banyak pada derajat sedang yaitu 10 responden (66.7\%) sedangkan sesudah pemberian minyak zaitun (olive oil) ruam popok pada bayi paling banyak pada derajat ringan yaitu 7 responden (46.6\%).

Tabel 4.3 DistribusiRataRataDerajat Ruam Popok Sebelum Dan SesudahPemberian Minyak Zaitun (Olive Oil) $(\mathrm{n}=15)$

\begin{tabular}{llllll}
\hline $\begin{array}{l}\text { Variab } \\
\text { el }\end{array}$ & $\begin{array}{l}\text { Mea } \\
\mathrm{n}\end{array}$ & SD & SE & $\begin{array}{l}\text { Min } \\
-\end{array}$ & $\begin{array}{l}\text { CI95 } \\
\text { Ma } \\
\text { ks }\end{array}$ \\
& & & \multicolumn{3}{c}{} \\
\hline $\begin{array}{l}\text { Deraja } \\
\text { t ruam } \\
\text { popok } \\
\text { sebelu }\end{array}$ & 1.67 & 0.4 & 2 & $1-2$ & 1.40 \\
m & & & & & \\
$\begin{array}{l}\text { Deraja } \\
\text { t ruam } \\
\text { popok } \\
\text { sesuda }\end{array}$ & 0.6 & 0.4 & 0.1 & $0-1$ & 0.31 \\
$\mathrm{~h}$ & & 5 & 1 & & \\
\hline
\end{tabular}

Tabel 4.3 menunjukkanbahwarerata derajat ruam popok pada respondensebelum pemberian minyak zaitunsebesar1.67 dengannilai minimal derajat ruam popok yaitu 1 dannilaimaksimalderajat ruam popok respondenyaitu 2. Dan rerata derajat ruam popok respondensetelah pemberianminyak zaitun (olive oil)sebesar0.6 dengannilai minimal derajat ruam popok respondenyaitu0, dannilaimaksimal derajat ruam popok respondenyaitu1.

\section{AnalisaBivariat}

Dalampenelitianini, analisabivariatdigunakanuntukmengana lisaperbedaanderajat ruam popok respondensebelumdansetelahpemberian minyak zaitun (olive oil) selama 3 hari berturut-turut dengan frekuensi pemberian 2 kali sehari pada pagi dan sore

hari.Dalamanalisisinipenelitimengguna kanujistatistikdenganuji T-test atauPaired T-test yaituujidua mean dependen. Perbedaan derajat ruam popok

respondensebelumdansetelahpemberian minyak zaitun (olive oil) penelitisajikandalambentuktabeldibawa hini:

Tabel4.4 PerbedaanDerajat Ruam PopokSebelum Dan SetelahPemberian Minyak Zaitun (Olive Oil) $(\mathbf{n}=15)$

\begin{tabular}{|c|c|c|c|c|c|}
\hline Variabel & $\begin{array}{c}\text { Mea } \\
\mathbf{n}\end{array}$ & SD & SE & $\begin{array}{l}\quad \text { CI } \\
95 \% \\
\text { Lowe } \\
\mathbf{r} \\
\text { Uppe } \\
\mathbf{r}\end{array}$ & $\begin{array}{l}\mathrm{V} \\
\mathbf{a} \\
\mathbf{l} \\
\mathbf{u} \\
\mathrm{e}\end{array}$ \\
\hline \multicolumn{6}{|l|}{$\begin{array}{l}\text { Derajat } \\
\text { ruam } \\
\text { popok }\end{array}$} \\
\hline $\begin{array}{l}\text { Sebelum } \\
\text { dan }\end{array}$ & $\begin{array}{c}1.10 \\
0\end{array}$ & $\begin{array}{c}0.20 \\
7\end{array}$ & $\begin{array}{c}0.05 \\
3\end{array}$ & & 0 \\
\hline Sesudah & & & & 0.985 & \\
\hline $\begin{array}{l}\text { Pemberi } \\
\text { am }\end{array}$ & & & & 1.215 & $\begin{array}{l}\text { 0 } \\
\text { 0 }\end{array}$ \\
\hline $\begin{array}{l}\text { Minyak } \\
\text { zaitun } \\
\text { (Olive }\end{array}$ & & & & & $\mathbf{0}$ \\
\hline
\end{tabular}


Oil)

Tabel4.4menunjukkan bahwa rata-rata nilai mean adalah 1.100 , dengan standar deviasi 0.207, didapatkan $p$ value $=0,000 \quad(<0,05)$. Maka dapat disimpulkan terdapat perbedaan yang signifikan rata-rata derajat ruam popok sebelum dan sesudah pemberian minyak zaitun (olive oil).

\section{PEMBAHASAN}

Pengaruh pemberian minyak zaitun terhadap ruam popok pada bayi di RSUD Bangkinang tahun 2016.

Berdasarkan hasil penelitian dan hasil analisis data tentang perbedaan derajat ruam popok sebelum dan setelah pemberian minyak zaitun (olive oil) adalah sebesar1.100 dengan menggunakan uji Paired Sample T-Test menunjukkan nilai $\mathrm{p}=0.000<\alpha=0,05$ yang berarti ada perbedaan yang signifikan terhadap derajat ruam popok pada bayi sebelum dan sesudah pemberian minyak zaitun (olive oil). Hasil penelitian menunjukkan derajat ruam popok pada bayi sebelum pemberiam minyak zaitun (olive oil) didapat rerata 1.67. sedangkan derajat ruam popok pada bayi setelah pemberiam minyak zaitun (olive oil) didapat rerata 0.6. Terjadinya penurunan atau selisih sebanyak 1.100.

Berdasarkan hasil observasi yang dilakukan peneliti di RSUD Bangkinang di ruangan anak (kelas 3) yaitu 1 ruangan terdiri dari 7 bed dan di dalam ruangan tersebut ada beberapa bayi yang dirawat dengan berbagai macam diagnosa diantaranya diare, peneliti mengobservasi bahwa rata-rata kebanyakan bayi yang mengalami ruam popok adalah bayi yang sedang mengalami penyakit diare, dan beberapa bayi lainnya yang tidak diare juga mengalami ruam popok hal ini disebabkan karena kurangnya ketelitian ibu dalam pemakaian popok sekali pakai, orangtua mengganti popok bayi paling sering hanya mengganti 2 kali sehari/setelah popok penuh/BAB, orangtua bayi memakaikan popok sepanjang waktu kepada bayinya tanpa membiarkan setidaknya 2-3 jam bayi terbebas dari popok supaya kulit terkena udara. Menerut asumsi peneliti rata-rata penyebab ruam popok pada bayi di RSUD Bangkinang karena bayi yang mengalami diare. Bayi yang diare lebih rentan terkena ruam popok karena frekuensi $\mathrm{BAB}$ yang sering pada saat bayi sedang diare, kondisi ini memudahkan terjadinya infeksi jamur atau kuman yang banyak terdapat dalam faces keadaan tersebut makin memburuk karena popok yang dipakai sangat ketat.

Menurut teori penyebab dari ruam popok adalah pemakaian pempers sekali pakai yang kurang baik. Pemakaian popok yang kurang baik seperti: pemakaian popok yang lama, kontak yang lama antara kulit dan popok yang basah mempengaruhi beberapa bagian kulit gesekan yang lebih sering dan lama menimbulkan kerusakan atau iritasi pada kulit yang dapat yang dapat meningkat permeabilitas kulit dan jumlah mikroorganisme. Dengan demikian kulit menjadi sensitif dan mudah mengalami iritasi.

Amonia juga penyebab ruam popok, peningkatan $\mathrm{pH}$ urine meningkatkan 
enzim fecal, yaitu protease dan lipose, sehingga memudahkan terjadinya iritasi pada daerah bokong. Enzim fecal juga meningkatkan permeabilitas kulit akibat garam empedu yang terkandung la faces, terutama pada saat diare (Nursalam, 2005). Melebihi daya tampung popok, tidak segera mengganti popok bayi setelah bayi $\mathrm{BAB}$, tidak membersihkan bokong bayi dan alat genitalia bayi setelah BAK/BAB atau sebelum memakaikan popok yang baru, pemakaian popok yang terlalu ketat, sehingga udara tidak masuk membuat kulit bayi menjadi lembab dan keadaan tersebut mempermudah tumbuhnya bakteri.

Faktor yang ikut berperan pada ruam popok adalah : kulit yang basah oleh urine dan faces, popok kotor yang berlangsung lama, keadaan oklusif atau tertutup oleh popok, kelembaban kulit. kurangnya pengetahuan orangtua responden tentang bagaimana cara menjaga kebersihan kulit bayi dan pakaian bayi misalnya jarang mengganti popok setelah bayi BAK, udara atau suhu lingkngan yang terlalu panas atau lembab, akibat mencret/diare, ataupun reaksi terhadap deterjen (Sudarti, 2010).

Untuk mengatasi berbagai terjadinya kerusakan kulit bayi akibat, terjadinya ruam popok pada bayi harus dilakukan upaya pencegahan terjadinya ruam popok dengan cara : ganti baju/popok bayi setiap kali basah (Ardhie, 2002). Sewaktu mengganti popok, bersihkan kulit secara lembut dengan air, gunakan sabun lembut setelah buang air besar, lalu bilas sampai bersih, keringkan dengan handuk atau kain halus dan lembut, anginkan sebentar, baru memakai popok yang baru, biarkan bayi tidak memakai popok selama paling sedikit 2-3 jam perhari agar kulit bayi tidak panas dan lembab oleskan bedak, krim atau salap untuk melindungi kulit agar mengurangi gesekan. Pemakaian bedak harus dilakukan pada keadaan kulit kering atau tidak basah, hindarkan ruam dari bedak seperti halnya debu, bedak juga berbahaya bagi paru-paru bayi (Marmi, 2011). Bedak juga juga dapat mengakibatkan ruam popok yang lebih parah karena bedak yang terletak dilipatan paha akan bercampur keringat yang dapat mengakibatkan tumbuhnya bakteri (Cahyati, 2015).

Untuk itu dipilih cara yang lebih tradisional yaitu pengobatan non farmakologi, salah satu dari bahan olahan alami yang dapat dipertimbangkan sebagai terapi topikal alternatif yang dapat digunakan untuk perawatan kulit pada bayi yang mengalami iritasi kulit pada daerah tertutup popok atau disebut dengan ruam popok yaitu : menggunakan minyak zaitun (olive oil) karena minyak zaitun akan menjaga kelembaban kulit. Minyak zaitun mengandung banyak senyawa aktif seperti fenol. Tokoferol, sterol, pigmen, squalene dan vitamin $\mathrm{E}$. Semua senyawa ini bermanfaat untuk kulit memperbaiki sel-sel kulit yang rusak sebagai antioksidan penetral radikal bebas mengurangi bekas kemerahan pada kulit dan dapat melindungi kulit dari iritasi (Apriyanti, 2012).

Menurut asumsi peneliti, menggunakan minyak zaitun (olive oil) secara rutin kepada bayi dan dioleskan secukupnya pada kulit bayi dapat mencegah/mengobati iritasi kulit (ruam 
popok) pada bayi, karena kandungan yang terdapat dalam minyak zaitun (olive oil) mampu melindungi kulit dari iritasi.

Setelah dilakukan intervensi pemberian minyak zaitun (olive oil) hasil analisis data didapatkan rata-rata derajat ruam popok sebelum pemberian minyak zaitun (olive oil) yaitu 1.67, dan ratarata derajat ruam popok setelah pemberian minyak zaitun (olive oil) yaitu 0.6. Hasil penelitian menunjukkan ada pengaruh pemberian minyak zaitun (olive oil) terhadap ruam popok pada bayi dengan selisih sebanyak 1.100 . Hasil penelitian ini sesuai dengan penelitian cahyati. (2015) yang menyatakan bahwa derajat ruam popok responden dapat berkurang setelah pemberian virgin coconut oil yaitu 2.32, dan sebelum pemberian virgin coconut oil yaitu 8.64 .

Hal ini disebabkan karena kandungan dalam virgin coconut oil hampir sama dengan kandungan dalam minyak zaitun (olive oil). Minyak zaitun (olive oil) mengandung banyak senyawa aktif seperti fenol. Tokoferol, sterol, pigmen, squalene dan vitamin E. Semua senyawa ini bermanfaat untuk kulit memperbaiki sel-sel kulit yang rusak sebagai antioksidan penetral radikal bebas mengurangi bekas kemerahan pada kulit dan dapat melindungi kulit dari iritasi (Apriyanti, 2012).

\section{KESIMPULAN}

Adapun hal yang dapat disimpulkan dari penelitian iniyaitusebagaiberikut:

1. Penelitianinitelahmengidentifikas ibeberapa karakteristik responden yang mengalami ruam popok di RSUD Bangkinang yang terdiridari15 orang responden. Penderitaruam popok di RSUD Bangkinang

terbanyakberjeniskelamin lakilaki danberada padarentangumur0-6bulan.

2. Rerataderajat ruam popokresponden yang mengalami ruam popoksebelumpemberian minyak zaitun (olive oil) selama 3 hari berturut-turut dengan frekuensi pemberian 2 kali sehari pada pagi dan sore hari yaitu 1.67.

3. Rerata derajat ruam popokresponden yang mengalami ruam popok setelahpemberian minyak zaitun (olive oil) selama 3 hari berturut-turut dengan frekuensi pemberian 2 kali sehari pada pagi dan sore hari adalah0.6.

4. Pemberian minyak zaitun (olive oil) selama 3 hari berturut-turut dengan frekuensi pemberian 2 kali sehari pada pagi dan sore hari berpengaruh terhadap derajat ruam popok pada bayi di RSUD Bangkinang.

\section{DAFTAR PUSTAKA}

Apriyanti, Maya. (2012). 10 Tanaman Obat Paling Berkhasiat \& Paling Dicari. Purwomartini Kalasan Sleman Yogyakarta: Pustaka Baru Press.

Ardhie, Ari, Muhandari. (2002).

Perawatan Kulit Bayi Dan

Balita. Jakarta: Fakultas

kedokteran Universitas

Indonesia.

Arikunto. (2006). Pedoman Riset Praktis Untuk Profesi Perawat. Jakarta: EGC 
Budiardja, Siti Aisah. (2005). infeksi kulit pada bayi \& anak. Jakarta: Fakultas kedokteran Universitas Indonesia.

Cahyati, Dwi, dkk. (2015). Pengaruh Virgin Coconut Oil Terhadap Ruam Popok Pada Bayi. Jurnal Keperawatan Sriwijaya, Volume 2 - Nomor 1, Januari 2015, ISSN No 23555459.

Fathoni, Ben. (2010). Mukjizat resep obat rasullah.Yogyakarta: itellectual (Data Media Grup).

Hidayat, Aziz, Alimul. ( 2011). Metode Penelitian Keperawatan Dan Teknik Analisis Data. Jakarta: Salemba Medika.

Kasjono \& Yasril. (2009). TeknikSampling Untuk Penelitian Kesehatan. Yogyakarta : Graha Ilmu.

Lokanata, Maya Devinta. (2004). Eksim Pada Bayi Dan Anak. Jakarta: Fakultas Kedokteran Universitas Indonesia.

Marmi. (2011). Panduan Lengkap Sakit Dan Luka Pada Anak .Yogyakarta: Pustaka Pelajar.

Meadow \& Simon. (2005). Lacture notes pediatrika, Edisi 7. Jakarta: Erlangga.

Nursalam, dkk, (2005). Asuhan Keperawatan Bayi Dan Anak, Edisi 1. Jakarta: Salemba Medika.
Notoadmodjo, Dr.Soekidjo. (2010). Metodologi Penelitian Kesehatan. Jakarta: Rineka Cipta.

Potter, P. A., \& Perry, A. G. (1997). Fundamentals of nursing: concepts, process, and practice. Diterjemahkan oleh Asih, Y., Sumarwati, M., Efriyani, D., Mahmuda, L., Panggabean, E., Kusrini., Kurnianingsih, S., Novieastari, E. Edt. Yulianti, D., Ester, M (2005). Buku ajar fundamental keperawatan konsep,proses, dan praktik, edisi 4, volume 1. Jakarta: EGC.

Ramba, Hardin, La \& Nurbaya, Siti. ( 2014). Kejadian Iritasi Kulit (Ruam Popok) Pada Bayi Usia 012 Bulan. Journal of Pediatric Nursing Vol. 1(2), pp. 087-092, April, 2014 Available online at http://library.stikesnh.ac.id. Diperoleh tanggal 12 Desember 2015.

Santrock, Jhon. (2011). Masa Perkembangan Anak. Jakarta: Salemba Humanika.

Sudarti, (2010). Kelainan Dan Penyakit Pada Bayi \& Anak. Yogyakarta: Muha Medika

Sugito, Titi, Lestari. (2002). Perawatan Kulit Pada Bayi Dan Balita. Jakarta: Fakultas Kedokteran Universitas Indonesia.

Yolanda, Oktari, dkk. (2013). Efektifitas Minyak Zaitun Terhadap Pressure Ulcers Pada Pasien Tirah Baring Lama. Jurnal keperawatan UNR 